\title{
Relationships of Paid and Unpaid Internships, and Source for Obtaining, to Early COVID-19 Stage Anticipated Employment Outcomes
}

\author{
Gary Blau ${ }^{1}$ \\ ${ }^{1}$ Fox School of Business \& Management, Temple University, Philadelphia, PA, USA \\ Correspondence: Gary Blau, Human Resource Management Dept., Fox School of Business \& Management, \\ Alter Hal \#349 (006-00) - 1801 Liacouras Walk, Temple University, Philadelphia, PA 19122, USA. Tel: \\ 1-215-204-6906. E-mail: gblau@temple.edu
}

Received: August 7, 2021

doi:10.20849/jed.v6i1.918
Accepted: September 10, 2021

Online Published: February 21, 2022

URL: https://doi.org/10.20849/jed.v6i1.918

\begin{abstract}
This study investigated the relationships of paid and unpaid internships to anticipated employment outcomes for graduating college business students. It also investigated the self-reported source(s) by which these students had obtained their internship(s). In May of 2020, 445 graduating business undergraduates filled out an online survey, for which there was complete data for 405 students. Although most of the internships were pre-pandemic, the anticipated employment outcomes by graduation were in the early stage of the COVID-19 pandemic. Three dichotomous response anticipated employment outcomes were measured: securing a full-time job; securing a full-time job that consistent with one's major; and being self- employed. Results were that students with at least one paid internship were more likely to anticipate securing a full-time job and securing a full-time job consistent with their major versus students without a paid internship. In addition, students with at least one paid internship were less likely to see themselves being self-employed versus students without a paid internship. However, there were no relationships for students having at least one unpaid internship, versus no unpaid internship, to these anticipated full-time employment outcomes. Students with at least one unpaid internship were more likely to see themselves being self-employed by graduation versus students without an unpaid internship. Surprisingly, the general source of "on my own" was the dominant method reported by students for obtaining both paid and unpaid internships. These results are further discussed, and study limitations noted.
\end{abstract}

Keywords: paid internship, unpaid internship, source for obtaining, anticipated employment outcomes

\section{Introduction}

\subsection{Introduce the Problem}

The initial COVID-19 pandemic negatively impacted employers hiring fewer college students for full-time jobs (Gray, 2021). Many businesses were reeling from reduced sales and having to layoff current employees. In their survey of approximately 1500 college students, Aucejo, French, Araya \& Zafar (2020) found that as a result of the COVID-19 pandemic onset, 13\% of students had delayed graduation, and $40 \%$ had lost a job, internship, or job offer. In their multi-country qualitative study (Hawley et al, 2021) found that with the COVID-19 pandemic, college students had concerns about finding employment and finding employment in their career field after graduation. It is important to study both types of employment outcomes, finding general employment versus finding employment in one's career field. Internships can be paid or unpaid (Blau \& Lopez, 2020; Hora, Chen, Parrott, \& Her, 2019; Jawabri, 2017). Prior college student research has not studied the relationships of paid versus unpaid internships/co-ops to anticipated employment in the early stage of the COVID-19 pandemic. That was one purpose of this study. A second purpose was to investigate how students obtained their internships.

\subsection{Relevant Prior Scholarship}

Internships have long been noted to be an important gateway to full-time job employment for college students (Knouse \& Fontenot, 2008; Sagen, Dallam \& Laverty, 2000). Blau, Snell and Goldberg (2021) found that college business students with at least one internship, versus those with no internships, were more likely to anticipate both outcomes of full-time employment by graduation and full-time employment within their major by graduation. Prior research has shown a distinction between these two outcomes, i.e., that a higher percentage of 
graduating business students anticipate full-time employment versus full-time employment in their major (Blau, Gaffney, Kim \& Jarrell, 2017).

As part of their education, business schools have supported their students' completing internships, cooperative education (co-ops) or practicums (Cook, Stokes \& Parker, 2015). Students often pay tuition to get formal course credit for an unpaid internship or co-op (Lei \& Yin, 2019). Blau and Lopez (2020) compared correlates of paid versus unpaid internships/co-ops for pre-pandemic graduating business undergraduates. Three one-item measures, answered yes or no, for anticipated employment by graduation were used: secured a full-time job; secured a full-time job that is consistent with your major; and started freelance work, consulting or are otherwise self- employed. Prior initial employment success research for college graduates has used this dichotomous measurement approach (Sagen et al., 2000). Blau and Lopez (2020) found a positive relationship between the number of paid internships and anticipated full-time employment by graduation but not to anticipated full-time employment in one's major or being self-employed. They also found a negative relationship for number of unpaid internships/co-ops to anticipated full-time employment, and a positive relationship to anticipated self-employment by graduation. One research question studied here was: would these relationships of paid versus unpaid internships to anticipated employment after graduation change when measuring anticipated employment outcomes early in the COVID-19 pandemic?

How college students obtain internships is also an important research issue. General recruitment source research has made a distinction between formal versus informal sources (Saks \& Ashforth, 1997), with formal involving the use of some type of formal intermediary or agent between the applicant and organization (e.g., college placement offices, advertisements, job fairs, search firms), while informal examples have included: referrals by friends and family; employee referrals; rehires, word-of-mouth, and walk-in, with an internship (leading to employment) being considered informal (Griffeth, Tenbrink \& Robinson, 2014). Shenoy and Aithal (2018) grouped internships with internal job posting, apprenticeships, and employee referrals. Rothman and Lampe (2010) found that for 381 undergraduates enrolled in a business school internship course for credit, a personal contact was given as the most likely source for obtaining the internship. These personal contacts included: family members, personal friends, and friends of the family (Rothman \& Lampe, 2010). Blau and Lopez (2020) found that the highest general source for obtaining both paid and unpaid internships that students self-reported was "on their own." However, Blau and Lopez (2020) did not investigate if this "on their own" method was still the dominant source for students doing only one versus multiple paid internships and unpaid internships/co-ops. In addition, not all research has shown "on their own" to be the dominant source for finding an internship. Jawabri (2017) found that two sources, college placement and professor/lecturer, accounted for 53\% of the reported paid and unpaid internship sources for his sample of United Arab Emirates business undergraduates. The second purpose of this study was to further explore the student-perceived source for obtaining their internship(s).

\subsection{Research Questions}

The above-cited literature leads to the following two research questions being investigated:

1 - Were there similar relationships of paid vs unpaid internships to anticipated employment by graduation during the early stage of the COVID-19 pandemic?

$2 \mathrm{a}$ - Was there a difference in source for how students obtained one paid versus unpaid internship?

$2 \mathrm{~b}$ - Was there a relationship between multiple reported paid versus unpaid internships and source(s) for obtaining these internships?

\section{Method}

\subsection{Participants and Procedures}

Graduating undergraduate business students, filled out an online survey in May, 2020 (early pandemic). The business school is part of a public university in the United States Mid-Atlantic region. Graduating business seniors voluntarily filled out the Senior Student Satisfaction Survey (SSSS) prior to graduation. They were sent periodic email reminders to do this. All study measures collected were part of the SSSS. A Qualtrics data base was used to store the data. In May 2020, 445 students filled out the SSSS, which represented approximately $37 \%$ of the graduating seniors. The sudden shift on March 13, 2020 (approximately half-way through the Spring semester) by the university to all remote (no in-person) classes, and students needing to move out of campus housing due to the pandemic, undoubtedly reduced the May 2020 voluntary participating sample size. The university institutional review board (IRB) approved the research as part of a general program review. Ninety-six percent of the sample were full-time students (taking at least 12 credits/semester), and had slightly higher male 
participants (52\%). For this study only a complete data sample was used, consisting of $n=405 / 445$ (91\%). The anonymity of students providing complete data was protected.

\subsection{Measures}

Internships or coops. Students were asked: "how many formal internships or co-ops did you complete as a student at this University?" Responses were made on a 6-point Likert type scale ranging from $1=0$ (none) to $6=$ 5 or more. An immediate follow-up item asked: "Of these internships or co-ops you completed, how many were unpaid?", with responses made using a 6-point Likert-type scale ranging from 0 (none) to 5 (5). The number of unpaid internships/co-ops answered was then subtracted from the total number of internships to determine paid internships (i.e., total internships - unpaid internships = paid internships). Blau and Lopez (2020) used this approach to successfully distinguish paid internships versus unpaid/coop internships.

After being asked about internships/co-ops, students were then asked, "If you have completed a formal internship or co-op, how did you obtain that position?" (Check all that apply). Five separate sources were listed: (a) through an SPO (Student Professional Organization (b) through the Business School Professional Development Center, (c) through the University Career Services, (d) through a professor or class, and (e) on your own. Thus, a student with multiple internships or co-ops could check different sources if relevant. Prior studies have worked with students having multiple internships (Dommeyer, Gross \& Ackerman, 2016). Eight (out of nine) departments in the Business School offer the same numbered unpaid internship/co-op course (3581) for academic credit every semester, Accounting, Finance, Human Resource Management, International Business (in the General Strategic Management Department), Legal Studies, Management Information Systems, Marketing, and Risk Management and Insurance. Only the Statistics Department did not offer a co-op course.

Record-based Intern Source Data. This data was collected from the Business School's Professional Development Center asking students to identify the source for obtaining one paid internship or one unpaid internship/co-op from Spring, 2018 through Fall 2019 (pre-pandemic) to Spring 2020 (early pandemic). These records further break down "on your own" into more specific sources. These sources included: Networking with Family/Friends; Networking with Faculty/Academic Department; Networking with Alumni; Applied Directly to Organization; Internet Job Posting (e.g., Monster); Previous Internship/Co-op; LinkedIn; Own Research; and Recruiting/Staffing Agency. These specific sources will be aggregated into the more general "on your own" source to allow comparison to the SSSS self-report data.

Anticipated employment outcomes. Three one-item measures were used. Students were asked, "by graduation, will you have: secured a full-time job?; secured a full-time job that is consistent with your major?; and started freelance work, consulting or are otherwise self- employed?" Responses for each of these items were $1=$ no or 2 $=$ yes. As noted above, research on prior initial employment success for college students has used this dichotomous measurement approach (Sagen et al., 2000). In addition, research has found the first two measures to be distinct, with a lower percentage of students expecting full-time employment consistent with their major versus expecting full-time employment (Blau et al., 2017). With the March 13, 2020 start of the COVID-19 pandemic for the students, surveying these students in May 2020 about their anticipated employment by graduation would be within the early stage of the pandemic (Aucejo et al., 2020).

\subsection{Data Analyses}

Using SPSS-PC (2018), student group were split into separate none (0) versus at least one paid internship and then none versus at least one unpaid internship. Independent sample t-tests were performed to test the first research question: are there similar relationships of paid vs unpaid internships to anticipated employment by graduation during the early stage of the COVID-19 pandemic? To test the related research questions asking if students used different sources to obtain one paid versus unpaid internship, and then different sources to obtain multiple paid versus unpaid internships, chi-square analyses and tests of independent proportions were performed. The record-based frequency count for one paid and one unpaid internship will also be reported as a general validity check.

\section{Results}

\subsection{Tests of Research Questions}

The independent samples t-test results are below in Table 1 . 
Table 1. Independent Sample T-tests Comparing No versus At Least One Paid and Unpaid Internship Groups to Spring 2020 Anticipated Employment Outcomes

$$
\begin{aligned}
& \text { Paid Internships } \\
& \quad(\mathrm{N}=405) \\
& \text { No } \quad \text { At least One } \\
& (\mathrm{N}=133) \quad(\mathrm{N}=272)
\end{aligned}
$$

Unpaid Internships

$(\mathrm{N}=405)$

No At least One

$(\mathrm{N}=297) \quad(\mathrm{N}=108)$

Anticipated Employment

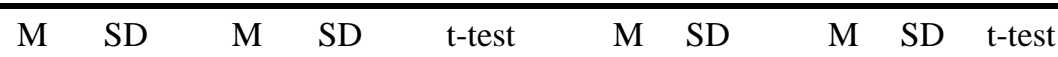

1. Securing FT Job by

Graduation $^{\mathrm{a}}$ $1.35-48$

$1.65-.48$

$-5.88 *$

$1.55+.50$

\section{Securing FT Job by}

Graduation in Major $^{\mathrm{a}}$

$1.27 \quad .45$

$-5.88^{* *}$

$1.55 \quad .50$

$\begin{array}{lll}1.57 & .50 & -.29\end{array}$

3. Being Self-employed

by Graduation ${ }^{\mathrm{a}}$

$1.16 \quad .37$

$1.08 \quad .27$

$2.33 *$

$1.09 \quad .28$

$1.17 \quad .37 \quad-2.00 *$

Note. $* \mathrm{p}<.05, * * \mathrm{p}<.01$ (all two-tailed)

${ }^{a}$ By graduation, will you have: secured a full-time job; secured a full-time job consistent with your major; started freelance work, consulting, or are otherwise self- employed, $1=$ no, $2=$ yes.

The results indicate that students with at least one paid internship perceived they were more likely to secure a full-time job by graduation and also secure a full-time job in their major, versus students with no paid internships. Perhaps, not surprising, given this anticipated employment, this same group of students were less like to believe they would be self-employed versus students with no paid internships. However, for students with no unpaid versus at least one unpaid internship there was no difference in being likely to secure a full-time job by graduation or secure a full-time job in their major. Yet, students with at least one unpaid internship were more likely to think they would be self-employed by graduation, versus students with no unpaid internships.

To test the second research question, first students with only one paid versus unpaid internship were compared on the self-reported source used to obtain that internship. This allowed the source for only one type of internship to be compared. The results are shown in Table 2 below.

Table 2. Comparison of Frequency Breakdown by Source for Obtaining One Paid versus Unpaid Internship

PAID

UNPAID

( $\mathrm{N}=123 / 149,26$ Missing $)$

$(\mathrm{N}=59 / 72,13$ Missing $)$

Source

Student Professional Organization

$22(17 \%)$

$2(3 \%)$

Business School Professional

Development Center

$8(7 \%)$

$4(7 \%)$

University Career Services

$6(5 \%)$

$6(10 \%)$

Professor or Class

$7(6 \%)$

$12(20 \%)$

On Your Own ${ }^{\mathrm{a}}$

$80^{\mathrm{c}}(65 \%)$

$35^{\mathrm{d}}(59 \%)$

Total

$123^{\mathrm{b}}$

$59^{\mathrm{b}}$

${ }^{\mathrm{a}}$ On your own further broken down by Business School Development Records into more categories, including: Networking with Family/Friends; Networking with Faculty/Academic Department; Networking with Alumni; Applied Directly to Organization; Internet Job Posting (e.g., Monster); Previous Internship/Co-op; LinkedIn; Own Research; Recruiting/Staffing Agency. 
${ }^{\mathrm{b}} 80 / 123=65 \%$ vs $35 / 59=59 \%, z=.75, p=.45 .10$ (two-tailed) no difference, on own $=$ dominant source, Source: http://vassarstats.net/propdiff_ind.html

${ }^{c}$ Paid, $65 \%$ on own versus rest of sources at 35\%, test of proportions with sample sizes of $80 \& 43$ entered $30 \%$ difference in proportions, Chi-square $=10.07, \mathrm{df}=1, \underline{\mathrm{p}}<.01$, so students more likely to use own versus all other 4 sources to find one paid internship. Source: https://www.medcalc.org/calc/comparison_of_proportions.php

${ }^{\mathrm{d}}$ Unpaid, $59 \%$ on own versus rest of sources at $41 \%$, test of proportions with sample sizes of $35 \& 24$ entered $18 \%$ difference in proportions, Chi-square $=1.82, \mathrm{df}=1, p=.18$, so students not more likely to use own versus all other 4 sources to find one unpaid internship. Source: https://www.medcalc.org/calc/comparison_of_proportions.php

Although the percentage using "on your own" was higher (65\%) for the one paid internship versus one unpaid internship/co-op (59\%), this difference was not significant, $z=.75, p=.45$. Tests of proportions within each group showed that while students were not more likely to use "on your own" versus all other sources combined for one unpaid internship, they were more likely to use "own your own" versus all other sources combined for one paid internship.

Table 3 (paid internships) and Table 4 (unpaid internships/co-ops) present the results for testing if there were differences in sources for obtaining multiple internships.

Table 3. Chi-Square Test and Test of Proportions for Multiple Paid Internships by Source for Obtaining Sources for Obtaining Paid Internships

Student Business School Professional University Professor On Your

Organization Development Center

Career Services or Class Own

\begin{tabular}{llccccc}
\hline Number of & Two & 8 & 7 & 3 & 1 & 42 \\
Paid Internships & & & 2 & 2 & 0 & 15 \\
& Three & 4 & 0 & 0 & 0 & 2 \\
& Four & 0 & 0 & 0 & 0 & 3 \\
& Five & 0 & 9 & 5 & 1 & $62^{\mathrm{a}}$ \\
\hline
\end{tabular}

Chi-Square $(12, \mathrm{n}=89)=3.52, p=.89$

${ }^{\mathrm{a}}$ Test of Proportions - Paid, 62/89 $=70 \%$ on own versus rest of sources at 30\% (27/89), test of proportions with sample sizes of $62 \& 27$ entered $40 \%$ difference in proportions, Chi-square $(1)=21.87=, p<.01$, so students more likely to use own versus all other 4 sources to find multiple paid internships. https://www.medcalc.org/calc/comparison_of_proportions.php

The results in Table 3 indicate a non-significant chi-square $(3.52, p=.89)$ for different sources in obtaining multiple paid internships. However, a test of proportions shows that students are more likely to use "on your own" versus all other sources combined to find multiple paid internships. 
Table 4. Chi-Square Test and Test of Proportions for Unpaid Internships by Source for Obtaining

\begin{tabular}{lcccccc} 
& \multicolumn{2}{c}{$\begin{array}{c}\text { Source for Obtaining Unpaid Internship } \\
\text { Student } \\
\text { Business School Professional } \\
\text { Organization }\end{array}$} & $\begin{array}{c}\text { University } \\
\text { Development Center }\end{array}$ & $\begin{array}{c}\text { Professor } \\
\text { Career Services }\end{array}$ & $\begin{array}{c}\text { On Your Class } \\
\text { Own }\end{array}$ \\
\hline $\begin{array}{l}\text { Number of } \\
\text { Unpaid }\end{array}$ & One & 2 & 4 & 6 & 12 & 35 \\
Internships & Two & 1 & 1 & 0 & 3 & 14 \\
& & & & & & \\
& Three & 0 & 0 & 0 & 0 & 3 \\
& Five & 0 & 0 & 0 & 0 & 1 \\
& Total & 3 & 5 & 6 & 15 & $53^{\mathrm{a}}$ \\
\hline
\end{tabular}

Chi-Square $(12, \mathrm{n}=82)=5.15, p=.85$

${ }^{\text {a }}$ Test of Proportions - Unpaid, 53/82 $=65 \%$ on own source versus rest of sources at $35 \%$ (29/82), test of proportions with sample sizes of $53 \& 29$ entered $30 \%$ difference in proportions, Chi-square $(1)=6.72=, p<.01$, so students more likely to use own versus all other 4 sources to find multiple unpaid internships.

https://www.medcalc.org/calc/comparison_of_proportions.php

The results in Table 4 indicate a non-significant chi-square $(5.15, p=.85)$ for different sources in obtaining multiple unpaid internships. The row for one unpaid internship needed to be included because of the low number for two or more unpaid internships. A test of proportions shows that students are more likely to use "on your own" versus all other sources combined to find multiple unpaid internships.

\subsection{Validity Check of Self-Report One Paid and One Unpaid Internship Source Data}

As noted earlier, record-based data was collected from the Business School's Professional Development Center asking students to identify the source for obtaining a paid internship or internship/co-op from Spring, 2018 through Fall 2019 (pre-pandemic) to Spring 2020 (early pandemic). These sources included: Networking with Family/Friends; Networking with Faculty/Academic Department; Networking with Alumni; Applied Directly to Organization; Internet Job Posting (e.g., Monster); Previous Internship/Co-op; LinkedIn; Own Research; and Recruiting/Staffing Agency. These files identify only one paid or one unpaid internship/student. These specific sources were aggregated into the "on your own" general source. Table 5 shows a record-based breakdown for one paid internship and one unpaid internship.

Table 5. Record-based Data for One Paid versus Unpaid Internship

PAID UNPAID

$(\mathrm{N}=326) \quad(\mathrm{N}=106)$

Source

\begin{tabular}{lll} 
Student Professional Organization & $58(18 \%)$ & $4(4 \%)$ \\
Business School Professional & & \\
Development Center & $50(15 \%)$ & $14(13 \%)$ \\
University Career Services & $6(2 \%)$ & $5(5 \%)$ \\
Professor or Class & $9(3 \%)$ & $12(11 \%)$ \\
On Your Own & $203(62 \%)$ & $71(67 \%)$ \\
Total & 326 & 106 \\
\hline
\end{tabular}

${ }^{\mathrm{a}}$ On your own further broken down by Business School Development Records into more categories, including: Networking with Family/Friends; Networking with Faculty/Academic Department; Networking with Alumni; Applied Directly to Organization; Internet Job Posting (e.g., Monster); Previous Internship/Co-op; LinkedIn; Own Research; Recruiting/Staffing Agency. 
A comparison of Table 5 to Table 2 indicates that according to the record-based data, the Business School Professional Development Center as the internship source is under-self-reported, while University Career Services and Professor or Class, as sources are over-self-reported. However, "on your own" still represents the dominant record-based source for both paid (62\%) and unpaid (67\%) internships, compared to the self-reported data (Table 2) for "on your own" as the source for a paid (65\%) and unpaid (59\%) internship. Despite these variations across individual sources, overall, the record-based data supports the general validity of the self-report data for one paid and one unpaid internship, particularly the dominant source of "on your own".

\section{Discussion}

Non-similar relationships of paid vs unpaid internships to anticipated employment by graduation during the early stage of the COVID-19 pandemic were found. The results indicate that students with at least one paid internship perceived they were more likely to secure a full-time job by graduation and also secure a full-time job in their major versus students without a paid internship. However, students with multiple unpaid internships were more likely to perceive being self-employed by graduation. These findings expand on the earlier non-pandemic findings by Blau and Lopez (2020). Students with at least one paid internship on their resume could feel they had a better chance to secure some type of full-employment during the early stage of the COVID-19 pandemic. Past research has shown that sometimes college students are able to turn an internship into a full-time position with the same organization (Lei \& Wen, 2019), as well as getting a good reference from the interning organization (Jawabri, 2017).

Students in this study more likely to report having at least one paid $(272 / 405=67 \%)$ paid versus unpaid $(108 / 405=27 \%)$ internship experience. These percentages are similar to prior studies (Hora et al., 2019; Jawabri, 2017). Despite the potential for gained knowledge and networking as advantages, affordability for students to take an unpaid internship/co-op, even if gives college credit, is one major drawback (Lei \& Yin, 2019). In their thematic analysis of data from 57 college students who interned, Hora, Parrott \& Her (2019) found the most salient terms were: experience, learning, paid, and connections. With at least one (versus none) unpaid internship/co-op(s) on their resume, students perceived they would be more likely be self-employed at the beginning of the COVI-19 pandemic. Since unpaid internship/co-op(s) would generally appear as college credit, i.e., a 15-week 3581 course, it may not appear as "credible" to a potential employer versus a longer duration paid internship (Lei \& Yin, 2019). Rogers, Miller, Flinchbaugh, Giddarie and Barker (2021) have argued that unpaid internships have less job structure, including lower task-related and knowledge-related job characteristics, and lower social-related work characteristics than paid internships. The perceived credibility of unpaid internships/co-ops versus paid internships to employers, for example in terms of quality of work-related experience, is a topic for future research.

It was surprising to find "on your own" to be such a dominant source finding for internships, both paid and unpaid versus college-related resources (Blau \& Lopez, 2020; Rothman \& Lampe, 2010). Although a comparison of the self-report data for one internship (Table 2) to record-based data (Table 5) showed that the Business School Development Center as the internship source for obtainment may have been under-reported, the "on your own source" was still dominant for the record-based data for both paid and unpaid/co-op internships. Prior empirical research has not formally investigated why this would be. Perhaps one reason is that college resources are the strongest during the academic year, i.e., Fall and Spring semesters, not over summer or winter break (December to January). For example, Student Professional Organizations (SPOs) only meet during the Fall and Spring semesters. The Business Professional Development Center and University Career Services are not as active during the summer or over winter break. Unpaid internships/coop classes are not offered over the summer at the Business School. Students may also feel they have more control/autonomy if they find an internship on own, versus perhaps feeling more "obligated" if a professor suggests or gets involved in helping the student to find an internship. By finding an internship "on their own" this can present students in a more favorable light, i.e., shows initiative, can do things independently, being a "go getter" (Poulis, 2021) when interviewing for a job. From an academic perspective, such "go getting" in a college student can be measured by self-efficacy or internal locus of control (Bean \& Eaton, 2000), or using self-promotion as an impression management strategy (Peck \& Levashina, 2017; Stevens \& Kristof, 1995). Comparing students who find internships "on their own" versus through other sources on such personality and/or impression management measures is an area for future research. Meanwhile as the Business School records showed, "on your own" can translate into many different year round sourcing methods, e.g., networking with family/friends; networking with alumni; applying directly to organization; Internet job posting (e.g., Monster); previous internship/co-op; LinkedIn; own research; and recruiting/staffing agency. Future research is needed to further investigate the reasons why "on your own" is 
such a dominant source for college students obtaining internships, including comparing these sources across different college majors.

\subsection{Study Limitations}

At least some if not most student internships, especially those with multiple experiences, occurred before the pandemic in March 2020 shut down the business school. Data on when the students did their internship(s) were not available. Furthermore it is not known if students were currently interning when the pandemic started. However, the pandemic would certainly have impacted on students' anticipated employment outcomes upon graduating in May, 2020. The "on your own" category in the survey was only a general source for obtaining an internship. This was further broken down into more specific sources, using record-based data from the Business School's Professional Development Center, and checked against the source for one paid and one unpaid self-reported internship. It was not possible to match self-reported SSSS source to record-based source data by student. Retrospective bias is introduced for students to remember source for obtaining an internship, especially those with multiple internships. Additional information, such as asking students to give the dates and length of each internship, and if not then name of the organization, than the type of organization (e.g., profit versus non-profit) would have increased the validity of this self-reported data.

As with prior research, there was a much smaller sample size for students having unpaid internships. Survey data was only gathered at early stage of pandemic, May 2020. It is not known if these results generalize to later time frames of the COVID-19 pandemic. Ideally future research should collect non-self-report data, such as the students' majors and specific jobs taken after graduation to determine what category they fit, e.g., full-time job consistent with major, self-employment.

The current sample consisted of full-time business students at a large, urban-centered, state supported University in the United States (US). Without additional data it would be difficult to generalize these results. For example, Hora et al. (2019) surveyed $n=1,1,29$ undergraduates across three different US colleges, with a follow-up focus group $(\mathrm{n}=57)$. Results indicated that internship participation varied significantly by institution (smaller rural campus - highest internship participation rate), enrollment status (part-time enrollment status - lower internship access), and academic program (lower GPA - lower internship access), and that $64 \%$ of students who did not take an internship had desired to do so but could not due to scheduling conflicts with work, insufficient pay, and lack of placements in their disciplines. Additional study of the relationships between paid internships, unpaid internships, complicating factors for interning, and employment outcomes is needed across different college settings.

\subsection{Conclusion}

This study takes a snapshot of the relationships of paid and unpaid internships to anticipated business student employment after graduating during the early COVID-19 pandemic. The ongoing COVID-19 pandemic has generally made it more challenging for college students to find jobs, especially in their major, after graduating. It should be assumed that many of the internships, paid and unpaid, were completed prior to the beginning of the COVID-19 pandemic. As such, these pre-pandemic internships were done face-to-face. However it is acknowledged that online internships, as with online learning, have become more popular as the impact of the COVID-19 pandemic continues. Research comparing online versus face-to-face internship experiences and outcomes for college students needs to be done. The "on my own", self-getting source for obtaining both paid and unpaid internships, as the dominant method, is in need of further study. For example, what role does self-efficacy, internal locus of control or self-promotion play for college students to use this self-getting source? Finally, research is needed exploring different employer motivations for creating paid versus unpaid internships, and the perceived credibility of paid versus unpaid internships to employers.

\section{References}

Aucejo, E., French, J., Araya, M., \& Zafar, B. (2020, November). The impact of COVID-19 on student experiences and expectations: Evidence from a survey. Journal of Public Economics, 191, 1-10. https://doi.org/10.1016/j.jpubeco.2020.104271

Bean, J., \& Eaton, S. (2001-2002). The psychology underlying successful retention practices. Journal of College Student Retention, 3(1), 73-89. https://doi.org/10.2190/6R55-4B30-28XG-L8U0

Blau, G., \& Lopez, A. B. (2020). Exploring correlates for paid versus unpaid internships or co-ops for graduating business students. Journal of Education for Business, 95(6), 393-401. https://doi.org/10.1080/08832323.2019.1668744 
Blau, G., Gaffney, M., Kim, Y. J., \& Jarrell, S. (2017). Do grading assessment learning perceptions correlate to post-graduation outcomes?. Journal of Assessment and Institutional Effectiveness, 7(1-2), 69-91. Retrieved from https://muse.jhu.edu/article/711009

Blau, G., Snell, C., \& Goldberg, D. (2021). Reinforcing the importance of maintaining internship support for college student engagement and anticipated employment. Journal of Education and Learning, 10(1), 1-6. https://doi.org/10.5539/jel.v10n1p1

Cook, J. S., Stokes, A., \& Parker, R. S. (2015). A 20-year examination of the perceptions of Business school interns: A longitudinal case study. Journal of Education for Business, 90(2), 103-110. https://doi.org/10.1080/08832323.2014.988201

Gray, K. (2021). College hiring rebounds to increase 7.2\%. National Association of Colleges and Employers. Retrieved from https://www.naceweb.org/job-market/trends-and-predictions/college-hiring-rebounds-to-increase-7-point-2percent/

Griffeth, W., Tenbrink, A., \& Robinson, S. (2014). Recruitment sources: A review of outcomes. In K. Yu, \& Cable, D. (Eds.), The Oxford Handbook of Recruitment (Chapter 13, pp. 215-226). Oxford: Oxford University Press.

Hawley, S., Thirvikraman, J., Noveck, N., St. Romain, T., Ludy, M. J., Barnhrt, L, .. Tucker, R. (2021). Concerns of college students during the COVID-19 pandemic: Thematic perspectives from the United States, Asia, and Europe. Journal of Applied Learning and Teaching, 4(1), 11-20. https://doi.org/10.37074/jalt.2021.4.1.10

Hora, M., Chen, Z., Parrott, E., \& Her, P. (2019). Problematizing college internships: Exploring issues with access, program design, and developmental outcomes in three U.S. colleges. WCER Working Paper No. 2019-1. University of Wisconsin-Madison, Wisconsin Center for Education Research. Retrieved from http://www.wcer.wisc.edu/publications/working-papers

Hora, M., Parrott, E., \& Her, P. (2020). How do students conceptualise the college internship experience? Towards a student-centred approach to designing and implementing internships. Journal of Education and Work, 33(1), 48-66. https://doi.org/10.1080/13639080.2019.1708869

Jawabri, A. (2017). Exploration of internship experience and satisfaction leading to better career rrospects among business students in UAE. American Journal of Educational Research, 5(10), 1065-1079. https://doi.org/0.12691/education-5-10-8

Knouse, S. B., \& Fontenot, G. (2008). Benefits of the business college internship: A research review. Journal of Employment Counseling, 45(2), 61-66. https://doi.org/10.1002/j.2161-1920.2008.tb00045.x

Li, S., \& Yin, D. (2019). Evaluating the benefits and drawbacks of internships: Perspectives of college students. College Student Journal, 53(2), 181-189. Retrieved from https://www.semanticscholar.org/paper/Evaluating-Benefits-and-Drawbacks-of-Internships\%3A-Lei-Yin/d 372e8ba329f87c737aa5915ff6fd9ec38caee18

Peck, J., \& Levashina, J. (2017). Impression management and interview and job performance ratings: A meta-analysis of research design with tactics in mind. Frontiers in Psychology, 8, 1-10. https://doi.org/10.3389/fpsyg.2017.00201

Poulis, E. (2021). How do you land your first job out of college?. College Voice. Retrieved August 5, 2021, from https://www.cnbc.com/2021/08/05/how-do-you-land-your-first-job-out-of-college.html

Rogers, S., Miller, C., Flinchbaugh, C., Giddarie, M., \& Barker, B. (2021). All internships are not created equal: Job design, satisfaction, and vocational development in paid and unpaid internships. Human Resource Management Review, 31(1), 1-13. https://doi.org/10.1016/j.hrmr.2019.100723

Rothman, M., \& Lampe, M. (2010). Business school internships: Sources and resources. Psychological Reports, 106(2), 548-554. Retrieved from https://journals.sagepub.com/doi/abs/10.2466/pr0.106.2.548-554

Sagen, H., Dallam, J., \& Laverty, J. (2000). Effects of career preparation experiences on initial employment success of college graduates. Research in Higher Education, 41(6), 753-767. https://doi.org/10.1023/A:1007072705601 
Shenoy, V., \& Aithal, P. (2018). Literature review on primary organizational recruitment sources. International Journal of Management, Technology, and Social Sciences, 3(1), 37-58. Retrieved from https://ssrn.com/abstract=3154270

SPSS. (2018). SPSS-PC (Version 25). Statistical package for the social sciences. Chicago: IBM Corporation.

Stevens, C., \& Kristof, A. (1995). A field study of applicant impression management during job interviews. Journal of Applied Psychology, 80(5), 587-606. https://doi.org/10.1037/0021-9010.80.5.587

\section{Copyrights}

Copyright for this article is retained by the author(s), with first publication rights granted to the journal.

This is an open-access article distributed under the terms and conditions of the Creative Commons Attribution license (http://creativecommons.org/licenses/by/4.0/). 